\title{
Article \\ Effects of Tray-Drying on the Physicochemical, Microbiological, Proximate, and Sensory Properties of White- and Red-Fleshed Loquat (Eriobotrya Japonica Lindl.) Fruit
}

\author{
Ilenia Tinebra (D), Roberta Passafiume (D), Dario Scuderi (D), Antonino Pirrone, Raimondo Gaglio (D), \\ Eristanna Palazzolo and Vittorio Farina *(D)
}

check for updates

Citation: Tinebra, I.; Passafiume, R.; Scuderi, D.; Pirrone, A.; Gaglio, R.; Palazzolo, E.; Farina, V. Effects of Tray-Drying on the Physicochemical, Microbiological, Proximate, and Sensory Properties of White- and Red-Fleshed Loquat (Eriobotrya Japonica Lindl.) Fruit. Agronomy 2022 12, 540. https://doi.org/10.3390/ agronomy12020540

Academic Editors: Anna Kocira, Katarzyna Panasiewicz and Ewa Szpunar-Krok

Received: 31 January 2022 Accepted: 16 February 2022 Published: 21 February 2022

Publisher's Note: MDPI stays neutral with regard to jurisdictional claims in published maps and institutional affiliations.

Copyright: (C) 2022 by the authors. Licensee MDPI, Basel, Switzerland. This article is an open access article distributed under the terms and conditions of the Creative Commons Attribution (CC BY) license (https:// creativecommons.org/licenses/by/ $4.0 /)$.
Department of Agricultural, Food and Forest Sciences (SAAF), Università degli Studi di Palermo, Viale delle Scienze, 90128 Palermo, Italy; ilenia.tinebra@unipa.it (I.T.); roberta.passafiume@unipa.it (R.P.); dario.scuderi@unipa.it (D.S.); antonino.pirrone@unipa.it (A.P.); raimondo.gaglio@unipa.it (R.G.); eristanna.palazzolo@unipa.it (E.P.)

* Correspondence: vittorio.farina@unipa.it; Tel.: +39-091-23896090

\begin{abstract}
Loquat fruits, highly valued by consumers for their characteristic aroma and pleasant taste have a short post-harvest life and are susceptible to mechanical damage, loss of firmness, and initial organoleptic characteristics. The aim of this work was to develop a drying method suitable for storing loquat fruits in polyamide/polyethylene (PA/PE) bags containing two gaseous mixtures (treatments): MAPN $_{2}\left(100 \% \mathrm{~N}_{2}\right)$ and MAPP $\left(21 \% \mathrm{O}_{2}\right.$ and $\left.0.04 \% \mathrm{CO}_{2}\right)$, at room temperature $\left(20 \pm 1{ }^{\circ} \mathrm{C}\right)$ for at least 2 months. The effects of these conditions on the physico-chemical, microbiological, proximate, and sensory properties of fruit stored over a 50-day time interval were studied. The results showed that convective tray dehydration treatment at $70^{\circ}$ for $12 \mathrm{~h}$ had good drying efficiency for loquat slices. In addition, the $\mathrm{MAPN}_{2}$ packaging limited the browning of the slices, keeping the microbial groups below the detection limits, with a clear positive effect on some minerals and vitamins, which were higher in concentration compared to the MAPP-packed samples. From an applicative point of view, the tray drying method for loquat fruits is useful on a small scale but could also be easily industrialized.
\end{abstract}

Keywords: loquat; dried fruit; modified atmosphere packaging; fruit quality; food safety; vitamins; minerals; sensory analysis

\section{Introduction}

Loquat (Eriobotrya Japonica Lindl.) is a subtropical evergreen fruit tree belonging to the Rosaceae family originating from southeastern China. Nowadays, loquat is cultivated in areas between the 25 th parallel south and the 38th parallel north in more than 30 countries across the globe. World production is estimated to be close to 200,000 tons, concentrated in China, Japan, Pakistan, Mediterranean countries (Spain, Algeria, Turkey, Cyprus, Egypt, Greece, Tunisia Israel, and Italy), and to a lesser extent Portugal, India, Brazil, Chile, and the United States.

Loquat was introduced to Italy at the beginning of the 19th century [1] and spread out into several countries, adapting to subtropical and temperate climates in the same areas where citrus can be grown [2]. In Italy, according to latest available data, loquat is cultivated almost completely on the northern coast of Sicily, especially in Palermo Province, where an area of 400 hectares and a harvested production of 4843 tons represent, respectively, $72.8 \%$ and $81.8 \%$ of Italian loquat production [3]. Here, loquat blooms in fall and early winter, and its white flowers give birth to spherical-oval red or white-fleshed pomes during late spring and early summer [4]. Loquat fruits are very aromatic with a pleasant taste [5], are a remarkable source of antioxidant phytochemicals, and may have chemopreventive effects at dietary amounts [6]. On the other hand, loquat fruit has a very short postharvest 
life and is sensitive to loss of moisture and firmness, mechanical and physical damage, and microbial decay [7]. Low-temperature storage is the most diffused method to extend postharvest life, but a large part of the cultivars are severely affected by chilling injuries during cold storage. Tissue leatheriness, internal browning, and lignin accumulation are major disorders. Furthermore, several fungal pathogens in many grown areas, including Alternaria alternata, Aspergillus niger, Botrytis cinerea, Colletotrichum gloeosporioides, Curlaria lunata, Diplocarpon mespili, Diplodia natalensis, Diplodia seriata, Geotrichum candidum, Fusarium solani, Mucor fragilis, Pestalotia sp., Phytophthora palmivora, Spilocaea pyracanthae, and Fusicladium eriobotrye, infest loquat $[8,9]$. The fruit is also subject to several physiological disorders, such as purple spot and russeting, that cause the loss of commercial value by affecting the visual appearance in many areas where loquat is grown [10,11]. The development of these chilling-related diseases and disorders limits loquat storage life and reduces consumer acceptance of this fruit. Hence, processing into jam, juice, canned or dried fruit, etc. can increase loquat shelf life and economic value compared to its fresh/unprocessed form [12]. Processing not only adds value, but increases returns on produce as well. It further increases market opportunities and improves shelf life to tackle seasonality and perishability [13].

Drying is probably one of the oldest methods of food preservation. Drying consists of the removal of water to a final concentration, which assures microbial stability and guarantees expected shelf-life of the product [14]. The aim of this process is to obtain the best quality attributes of the product, and it is related to how it will be used. Drying occurs through the vaporization of liquid by supplying heat to whole fruit, fruit chips, or pieces/slices by conduction (contact or indirect dryers), convection (direct dryers), radiation, microwave, or radio frequency electromagnetic methods. There are different single or combined drying methods applied to different varieties of fruits under different preservative solution, and with different effects on drying kinetics and quality parameters. Sun dried fruits and fruit products are the best known of all dried foods. Conventional open sun drying permits a product with good qualitative traits, but it is subject to environmental contamination and the process is slow. Hot air drying is an alternative method that decreases dehydrating time and improves the quality of the final product. There are many dryers used in domestic and industrial application such as spray dryers, freeze dryers, vacuum dryers, fluidized bed dryers, tray dryers, etc. This last one is the most used for fruit because of its easy and economic design [15], using a hot air stream across the whole chamber with forced circulation to dry the fruit. Moreover, tray drying increases the shelf-life of the fruit, reduces packaging cost, allows lower shipping weights with environmental advantages, and reduces fruit waste (market-rejected fruit), while offering a new fruit-derived product.

Tray drying application on the most cultivated tropical fruit such as banana [16], mango [17], papaya [18] and pineapple [19] has been recently studied. To date, only a few studies have been conducted on loquat concerning the application of different drying technologies on fruit texture and antioxidants [20], chemical and microstructural properties [21], carotenoids, and volatile compounds [22], or on the development of mathematical models $[23,24]$. Therefore, the influence of tray drying in loquat and the quality properties of the obtained product are not well acknowledged. The temperature of the drying air is one of the principal parameters of this process, since it influences the drying kinetics and the physicochemical properties of the dry product [16]. Changes in structure occur during drying process depending on the composition and nature of the fruit and the drying technique, influencing the fruit's physical-chemical and sensory properties [21]. Shrinkage and shape distortions, browning, fading of natural color or discoloration, decreased flavor, gumminess, or juiciness are the most undesirable effects of drying [14]. Inactivation of enzymes is necessary to cease such oxidation reactions and prevent browning. For this purpose, loquat fruit has been preserved with sodium bisulfite, sodium benzoate, and potassium metabisulphite to avoid enzymatic browning $[20,21,23]$. However, there is an increasing consumer demand for natural products with anti-browning compounds [25]. 
Among the natural anti-browning agents extensively used to control browning citric acid and ascorbic acid are weak organic acids found in fresh fruits and vegetables [26]. The use of these compounds would be of indubitable importance for more widespread consumer acceptance of dried products. Actually, the drying of fruit on a commercial scale has received a resurgence of interest during the past years considering the importance of these products to human health $[27,28]$. The potential industrial uses of dried fruit snacks and their by-products include their use as an ingredient in bakery and confectionery products or as additives to several cereal-based products, yogurts, and cheeses.

Thus, the objective of this work was to set up a tray drying method for red- and white-fleshed loquat fruit and investigate the influence of the drying on the fruit's physicochemical, proximate, microbiological, and sensory properties, analyzing a long period of storage. Therefore, we studied different air drying temperatures to determine the best drying condition for loquat slice production, and examined the behavior of slice over 50 days of storage in passive and modified atmosphere packaging (MAP). The practical applications are to develop a simple and low-cost convective drying method that could be widely used in fruit loquat processing and in small/large scale manufacturing to obtain a new product characterized by a high shelf life.

\section{Materials and Methods}

\subsection{Vegetal Material}

Ripe loquat fruits (Eriobotrya japonica L.) at the stage 809 on the BBCH scale [29], ripe for consumption with typical taste and firmness, were used. Ripe fruit was used to prevent the waste of produce through the application of hot air dehydration. We selected whitefleshed fruit (Cv. Claudia) and red-fleshed fruit (Cv. Peluche) grown in Sicily. Both redand white-fleshed cultivars presented a high percentage of damaged fruit with spots on the fruit. Consequently, part of the yield fetches a very low price on the market (about $1 €$ ) because of its damaged appearance [30], and drying could valorize this production. Fruit was harvested in a commercial orchard located in the village of S. Maria di Gesù, Palermo (Sicily, Italy; $38^{\circ} 04^{\prime} \mathrm{N}, 13^{\circ} 22^{\prime} \mathrm{E}, 150 \mathrm{~m}$ a.s.l.) from adult trees spaced $5 \times 5 \mathrm{~m}$ and cultivated according to the protocols of organic agriculture. Twenty kilograms of fruits (fruit average weight $54 \pm 7.7 \mathrm{~g}$ ) were hand-picked randomly from 10 trees using skin color as harvest index [22].

\subsection{Experimental Design}

Different preliminary tests on loquat fruit dehydration were carried out with the aim of finding the right time/temperature combination and whether to dehydrate the fruit with or without its skin. For this reason, the initial experimental protocol involved the use of two different dehydration temperatures (applied to both cultivars with and without skin):

- Thesis 1: dehydration at $50{ }^{\circ} \mathrm{C}$ for $12 \mathrm{~h}$;

- Thesis 2: dehydration at $70{ }^{\circ} \mathrm{C}$ for $12 \mathrm{~h}$.

Raw fruits were washed with distilled water $\left(5^{\circ} \mathrm{C}\right)$ and sanitized in $200 \mu \mathrm{L} \cdot \mathrm{L}^{-1}$ Ox-Virin (solution of hydrogen peroxide and peroxyacetic acid; $0.5 \% w / v$ ) for $10 \mathrm{~min}$. Subsequently, the fruits were peeled, seeded, and cut in half longitudinally with a curved knife obtaining two slices. Then, the slices were treated using the dipping technique [31] with an antioxidant solution to prevent browning, which contained citric acid and ascorbic acid, natural anti-browning agents, in concentrations of $0.5 \mathrm{~g} / 0.5 \mathrm{~L}$ of distilled water, for $5 \mathrm{~min}$. A tray dryer (Ausla, 1000 watt, Italy) was used to dry the fruit for $12 \mathrm{~h}$ at the selected temperature.

The dehydrated fruits were stored by modified atmosphere packaging (MAP) technology, in polyamide/polyethylene (PA/PE) bags, with either a mixture containing 100\% $\mathrm{N}_{2}\left(\mathrm{MAP} \mathrm{N}_{2}\right.$ ) or in passive-MAP conditions (MAP P-21\% $\mathrm{O}_{2}$ and $0.04 \% \mathrm{CO}_{2}$ ) at room temperature $\left(20 \pm 1^{\circ} \mathrm{C}\right)$ for 50 days. 
Analyses were carried out every 10 days $\left(\mathrm{T}_{10} ; \mathrm{T}_{20} ; \mathrm{T}_{30} ; \mathrm{T}_{40} ; \mathrm{T}_{50}\right)$ and samples were divided as follows: $200 \mathrm{~g}$ of dehydrated loquat slices per bag $\times 3$ bags for treatments $\times 5$ storage times, for each cultivar.

Loquat slices were stored using PA/PE bags composed at PA 80\%-PE 20\%, $90 \mu \mathrm{m}$ in thickness and $500 \mathrm{~cm}^{3}$ in volume, with an oxygen permeability of $47.6 \mathrm{~cm}^{2} /\left(\mathrm{m}^{2}\right.$ day atm) and a water vapor transmission rate of $3.9 \mathrm{~g} /\left(\mathrm{m}^{2}\right.$ day atm) [32].

Modified atmosphere was obtained inside the sealed bags using a digitally controlled packaging machine (VM 16 Orved S.p.A, Musile di Piave, Venezia, Italy).

The treatments were as follows:

1. $\mathrm{MAPN}_{2}$ white-flesh cultivar;

2. $\mathrm{MAPN}_{2}$ red-fleshed cultivar;

3. MAPP white-fleshed cultivar;

4. MAPP red-fleshed cultivar.

\subsection{Physico-Chemical Analysis}

Fruit weight, longitudinal diameter, transverse diameter, color, firmness, total soluble solids content, and titratable acidity were analyzed on a sample of 30 raw fruits per cultivars.

Fresh weight (FW-g) was measured with a precision electronic scale (Gibertini EU-C 2002 RS, Novate Milanese, Italy), while the fruit longitudinal diameter (LD-mm) and fruit transverse diameter (TD-mm) was measured with a digital caliper (Turoni TR53307, Forli, Italy). Color of fruit slices was determined on basis of CIE $L^{*} a^{*} b^{*}$ color system (CIE $L^{*} a^{*} b^{*}$ : lightness $\left(L^{*}\right)$; redness / greenness $\left(a^{*}\right)$; yellowness/blueness $\left(b^{*}\right)$; chroma $\left(C^{*}\right)$; Hueangle $\left(h^{\circ}\right)$ measured using a digital colorimeter (CR-400 Chroma Meter, Minolta, Japan). Calibration of the color meter was performed against a white tile background (Illuminants C: $\mathrm{Y} \frac{1}{4} 89.53$, $\mathrm{x} \frac{1}{4}$ 0.3247, y $\frac{1}{4}$ 0.3198) prior to each measurement.

For each slice, color parameters $\left(L^{*}, a^{*}\right.$, and $\left.b^{*}\right)$ were measured and means of all measurements were determined for each package.

The color differences $(\Delta E)$ between the colors at each evaluation time for the fruit slices of each cultivar and the color of the fruit slice were measured at $\mathrm{T}_{0}$, following the Equation (1):

$$
\Delta E=\left(L^{*}-L_{0}^{*}\right)^{2}+\left(a^{*}-a_{0}^{*}\right)^{2}+\left(b^{*}-b_{0}^{*}\right)^{2}
$$

where $L_{0}^{*}, a_{0}^{*}$, and $b_{0}^{*}$ represent the values of the color parameters measured after dehydration of the loquat slices.

Chroma $\left(C^{*}\right)$ values, which indicate the quantitative attribute of color intensity, and hue angles $\left(h^{\circ}\right)$, which are considered as the qualitative attribute of color of samples, were calculated using Equations (2) and (3), respectively:

$$
\begin{aligned}
& C^{*}=\left(a^{* 2}+b^{* 2}\right)^{\frac{1}{2}} \\
& h^{\circ}=\arctan \left(\frac{b^{*}}{a^{*}}\right)
\end{aligned}
$$

The firmness of the slices was measured using a durometer (Durofel Agrosta 100Field, Serqueux, France) and converted to Newtons using Equation (4) [33]:

$$
N=9.8\left(e^{\frac{\text { Durofel- }-59.32}{14.89}}\right)
$$

Total soluble solids content (TSSC Brix) was measured by a digital refractometer (Atago, Tokyo, Japan) and expressed as ${ }^{\circ}$ Brix, and titratable acidity (TA g/L) were measured using a $\mathrm{pH}$ meter-titrator (Titromatic 1S, Crison, Barcelona, Spain) and expressed as grams of malic acid per liters of crude loquat juice $\left(\mathrm{g} \mathrm{L}^{-1}\right.$ malic acid) and was determined by titration to an end point of $\mathrm{pH} 8.2$ using $5 \mathrm{~mL}$ of juice diluted with $10 \mathrm{~mL}$ distilled water. 
The dried fruit slices were checked for drying efficiency (DR\%), which was calculated using Equation (5) [34]:

$$
\% D R=\frac{(c-a)}{(b-a)} \times 100
$$

$a=$ weight of the empty tray;

$b=$ weight of the tray with the product before drying;

$c=$ weight of the tray with the product after drying.

After dehydration and before packing in MAP, on a representative sample of 30 pieces of fruit, both for Claudia and Peluche cultivars, the following parameters were assessed for all treatments:

- Color;

- Firmness (N);

- Longitudinal Diameter;

- Transverse Diameter.

while the fruit length—longitudinal diameter $(\mathrm{mm})$, and fruit width—transverse diameter $(\mathrm{mm})$ with a digital caliper.

Analyses were presented as mean \pm standard deviation (SD) of ten replicates. These analyses were repeated at 10-day intervals for a period of 50 days of storage at room temperature $\left(20 \pm 1^{\circ} \mathrm{C}\right)$ after opening the bags.

\subsection{Microbial Analysis}

Ten grams of fresh and dehydrated sliced loquat samples from each cultivar and treatment were transferred into a sterile stomacher bag (BagLight 400, Interscience, Saint Nom, France) added with $90 \mathrm{~mL}$ of Ringer's solution (Sigma-Aldrich, Milan, Italy) and homogenized in a BagMixer 400 (Interscience) for $3 \mathrm{~min}$ at the highest speed. Homogenized samples were then serially diluted (1:10) and the cell suspensions were used for the search of the main microbial groups belonging spoilage and pathogenic populations by plate count following the approach of Passafiume et al., 2021 [35]. Briefly, total mesophilic microorganisms (TMM) and total psychotrophic microorganisms (TPM) were detected on plate count agar (PCA), Pseudomonas spp. on Pseudomonas agar base (PAB) added with fucidin cephaloridine supplement (CFC), members of the Enterobacteriaceae family on violet red bile glucose agar (VRBGA), yeasts and molds on yeast extract peptone dextrose (YPD) agar supplemented with chloramphenicol $(0.1 \mathrm{~g} / \mathrm{L})$ to prevent bacterial growth, Listeria spp. on Listeria selective agar base with SR0140E supplement, and Salmonella spp. and Escherichia coli on Hektoen enteric agar (HEA). All plate counts were performed by spreading, except those for Enterobacteriaceae, which were performed by pouring VRBGA plated by pour plate [36]. All media were purchased from Microbiol Diagnostici (Uta, Italy). Microbiological analyses were performed in duplicate.

\subsection{Proximate Composition}

The ascorbic acid (Vitamin C) and the retinol (Vitamin A) were determined according to procedures previously described by Barros et al., 2007 [37]. For this determination, the dried methanolic extract $(100 \mathrm{mg}$ ) was extracted with $10 \mathrm{~mL}$ of $1 \%$ metaphosphoric acid for $45 \mathrm{~min}$ at room temperature and filtered through Whatman no. 4 filter paper. The filtrate $(1 \mathrm{~mL})$ was mixed with $9 \mathrm{~mL}$ of 2.6-dichlorophenolindophenol and the absorbance was measured within $30 \mathrm{~min}$ at $515 \mathrm{~nm}$ against a blank. Vitamin C and Vitamin A were calculated on the basis of the calibration curve of authentic L-ascorbic acid $(0.02-0.12 \mathrm{mg} / 100 \mathrm{~g})$. The contents of $\mathrm{Ca}, \mathrm{Mg}, \mathrm{K}, \mathrm{Na}$, and $\mathrm{P}$ were determined using atomic absorption spectroscopy following wet mineralization, while $\mathrm{P}$ was determined using a colorimetric method [38]. All measurements were done in three replicates. 


\subsection{Sensory Evaluation}

Sensory evaluation was performed by a team of 30 judges (sixteen men and fourteen women aged between 20 and 60 years) with a good background and knowledge of the details of this kind of food evaluation [39], following the guidelines of UNI 10957:2003 legislation [40]. During the preliminary meetings, 14 qualitative descriptors were chosen for the definition of the sensory profile, generated based on citation frequency $(>60 \%)$ and listed below: visual appearance (VA); color (CL); browning (BR); loquat odor (OL); honey odor $(\mathrm{OH})$; off-odor (OO); crispness (FF); softness (GM); juiciness (JUI); loquat flavor (FL); caramel flavor (FC); sweetness (SW); acidity (AC); and sourness (SO).

The evaluation was carried out from 10.00 a.m. to 12.00 p.m. in a room under white lights. Each panelist received in random order a sample of three fruit slices for each cultivar and each treatment, and water was provided for rinsing the mouth between each sample.

The judges evaluated the intensity of each descriptor by assigning a score between 1 and 9, where each score represented a different level of intensity of the quality descriptors. The panelists assigned scores to the descriptors according to the nine-point intensity scale: 1-no sensation, 2-barely recognizable, 3-very weak, 4-weak, 5-light, 6-moderate, 7-intense, 8-very intense, and 9-extremely intense [3].

\section{Statistical Analysis}

Using R software (R Core Team, 2013), repeated measures ANOVA and Bonferroniadjusted pairwise $t$-tests $(p \leq 0.05)$ were carried out for all studied parameters in order to assess significant differences between the means of the treatments.

\section{Results and Discussion}

\subsection{Fresh Fruit}

Before proceeding with the dehydration of the loquat fruits, chemical-physical characterization of the samples was carried out on 30 raw fruits for both cultivars. By commercial classification, that is, based on the transverse diameter of the fruits [41] (classes: GGG > $53 \mathrm{~mm}$, GG: $46-52 \mathrm{~mm}, \mathrm{G}: 32-45 \mathrm{~mm}$ and M: 31-28 $\mathrm{mm}$ ), the fruits of both cultivars belong to the commercial category $\mathrm{G}$.

The results of the color study (Table 1 ) show that the brightness $\left(L^{*}\right)$ of the pulp is higher in white-fleshed fruit (Claudia) than in yellow-fleshed fruit (Peluche), reflecting the more intense color, which depends on the higher accumulation of carotenoids [42]. The $a^{*}$ (redness/greenness) and $b^{*}$ (yellowness/blueness) values were much greater in Peluche. Alternatively, the color was well-described by $h^{\circ}$ as follows: $0^{\circ}$ for red-purple and $90^{\circ}$ for yellow [43]. Therefore, with hue angles of $1.14^{\circ}$ and $0.96^{\circ}$, the peel color of white-fleshed and red-fleshed cultivars tends to be yellow and orange, respectively.

Table 1. Values of CIE $L^{*} a^{*} b^{*}$ coordinates measuring both cultivars, with values of chroma and hue angle (lightness $\left(L^{*}\right)$; redness $\left(a^{*}\right)$; yellowness $\left(b^{*}\right)$; chroma $\left(C^{*}\right)$; hue angle $(h)$. Data correspond to the means \pm SD

\begin{tabular}{cccccc}
\hline Cultivars & $\boldsymbol{L}^{*}$ & $\boldsymbol{a}^{*}$ & $\boldsymbol{b}^{*}$ & $\boldsymbol{C}^{*}$ & $\boldsymbol{h}^{\circ}$ \\
\hline Claudia & $66.01 \pm 0.19$ & $11.20 \pm 0.21$ & $24.49 \pm 0.23$ & $26.75 \pm 0.33$ & $77.20 \pm 4.62$ \\
Peluche & $60.00 \pm 0.17$ & $24.60 \pm 0.09$ & $35.00 \pm 0.29$ & $42.78 \pm 0.61$ & $70.85 \pm 3.18$ \\
\hline
\end{tabular}

Table 2 shows the results of the physico-chemical analysis of both cultivars. Peluche shows a higher content of TSSC than Claudia. The cultivar 'Claudia' shows the highest consistency. These data are similar to that reported by Insero et al., 1993, for loquat fruits of the same cultivars grown in Palermo [44]. Both cultivars showed similar values to the TSSC observed by $\mathrm{Xu}$ and Chen, 2011 [45] and Hasegawa et al., 2010 [46]. Finally, the cultivar Peluche reached the highest level of the TSSC/TA ratio, which indicates a sweeter fruit $[3,6]$. 
Table 2. Values of TSSC (total soluble solids content, Brix); TA (titratable acidity, $\mathrm{g} \mathrm{L}^{-1}$ malic acid); TSSC/TA ratio; FF (firmness; N) measured on both cultivars. Values represented as mean \pm SD.

\begin{tabular}{ccccc}
\hline Cultivars & TSSC & TA & TSSC/TA & FF \\
\hline Claudia & $9.11 \pm 0.16$ & $0.69 \pm 0.07$ & 13.20 & $30.90 \pm 0.18$ \\
Peluche & $12.33 \pm 0.21$ & $0.82 \pm 0.09$ & 15.04 & $25.00 \pm 0.22$ \\
\hline
\end{tabular}

\subsection{Preliminary Test}

Table 3 refers to the preliminary test carried out in order to choose the best "timetemperature" combination to obtain a high-quality dehydrated product. The best maintains the organoleptic and nutritional characteristics of the fresh fruit. The principle of dehydration is to reduce water content to increase the shelf-life of the product [47]. Our data show that the value of the $\mathrm{DR} \%$ is about $40 \%$, after a period of dehydration at $50{ }^{\circ} \mathrm{C}$ for $12 \mathrm{~h}$. The fruits of both cultivars were particularly browned, as can be seen from the colorimetric values (Table 3), and gummy to the touch, characteristics not appreciated by consumers in dehydrated products [48]. The enzymatic browning could be due to the destruction of carotenoids, as reported by Mazzaglia et al., 2020 [40]. For this reason, the treatment at $50{ }^{\circ} \mathrm{C}$ for $12 \mathrm{~h}$ was not applied and we proceeded only with the application of a hot air dehydration treatment at a temperature of $70^{\circ} \mathrm{C}$ for $12 \mathrm{~h}$, which also gave the best results in chemical-physical parameters in the preliminary test (data not shown).

Table 3. Results of the analyses of CIE $L^{*} a^{*} b^{*}$ coordinates, with values of chroma $\left(C^{*}\right)$, hue angle $\left(h^{\circ}\right)$, color variation $(\Delta E)$, and drying efficiency $(\mathrm{DR} \%)$. Values represented as mean $\pm \mathrm{SD}$.

\begin{tabular}{|c|c|c|c|c|c|c|c|}
\hline $\begin{array}{c}\text { Time- } \\
\text { Temperature } \\
\text { Combination }\end{array}$ & $L^{*}$ & $a^{*}$ & $b^{*}$ & $C^{*}$ & $h^{\circ}$ & $\Delta E$ & DR\% \\
\hline $\begin{array}{c}50{ }^{\circ} \mathrm{C} \\
\text { for } 12 \mathrm{~h}\end{array}$ & $46.04 \pm 0.22$ & $12.95 \pm 0.19$ & $39 \pm 0.24$ & $40.90 \pm 0.10$ & $1.24 \pm 0.21$ & $14 \pm 0.03$ & $39.07 \pm 0.15$ \\
\hline
\end{tabular}

\subsection{Longitudinal and Transverse Diameter and Dry Residue (DR\%)}

Concerning the Claudia $\mathrm{Cv}$., as shown in Figures 1 and 2, the longitudinal diameter (LD) and the transverse diameter (TD) decreased with the dehydration process. In particular, before dehydration, the loquat slices had a LD of $50.59 \mathrm{~mm}$ and a TD of $43.04 \mathrm{~mm}$. After dehydration, the values decreased to 35.22 and $32.70 \mathrm{~mm}$, respectively. Thus, the dehydration process reduced the LD of loquat slices by $15.37 \mathrm{~mm}$ and the TD by $10.34 \mathrm{~mm}$. Comparing these data with DR\% showed a water content loss of $87.08 \%$. After 50 days of storage, the LD was further reduced by $9.41 \mathrm{~mm}$ and the TD by $8.07 \mathrm{~mm}$ in MAP $\mathrm{N}_{2}$-treated slices, while MAP P-treated slices were reduced in diameters (LD and TD) by 7.75 and $6.86 \mathrm{~mm}$, respectively. Thus, dehydrated white-flesh loquat treated with MAP P lost more water content at the end of the storage period; in fact, their diameter decreased more than the fruits treated with MAP $\mathrm{N}_{2}$.

For Peluche $\mathrm{Cv}$, the LD before dehydration was $48.93 \mathrm{~mm}$, while the TD was $44.12 \mathrm{~mm}$. After dehydration, these values decreased to 36.65 and $31.95 \mathrm{~mm}$, respectively, reducing by about $12 \mathrm{~mm}$. Thus, after dehydration, loquat slices lost $87.17 \%$ of their DR\%. However, the differences between the MAP $\mathrm{N}_{2}$ and MAP P treatments, detected over up to 50 days of storage, were as follows: the data from the MAP $\mathrm{N}_{2}$ treatment showed that the LD decreased by a further $11.62 \mathrm{~mm}$, while the TD decreased by a further $9.86 \mathrm{~mm}$, whereas the LD of MAP P lost $9.16 \mathrm{~mm}$ and the TD lost $8.16 \mathrm{~mm}$. Therefore, according to these data, the best treatment seems to have been MAP $\mathrm{N}_{2}$, probably due to the $\mathrm{N}_{2}$ inside the bags. In fact, according to different studies $[39,49,50]$, the $\mathrm{N}_{2}$ alone or in combination with other gases seems to improve the shelf-life of the fruit by influencing water vapor transmission. In addition, previous studies [5] report consumer preferences towards larger fruits, although with unaltered organoleptic characteristics. 
The effects of dehydration do not seem to be influenced by the type of fruit, as both red and white-fleshed products showed the same DR\%.

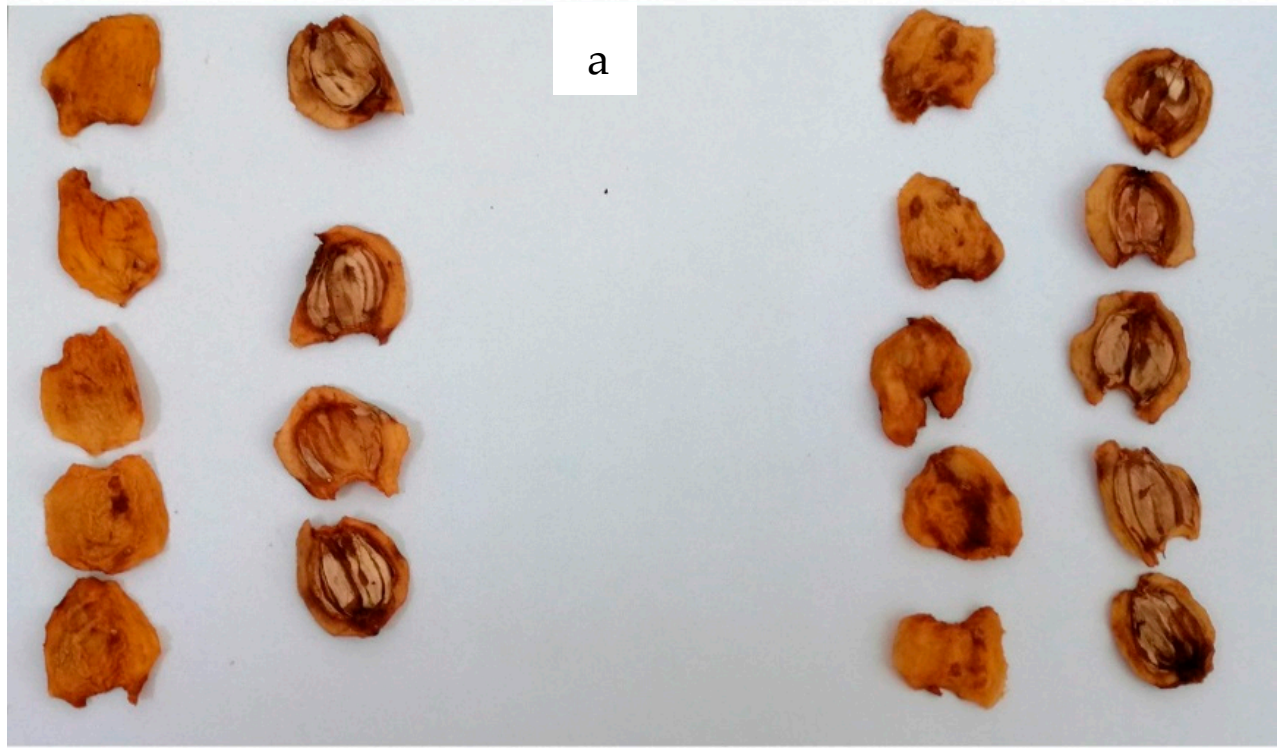

MAP $\mathrm{N}_{2}$
MAP P
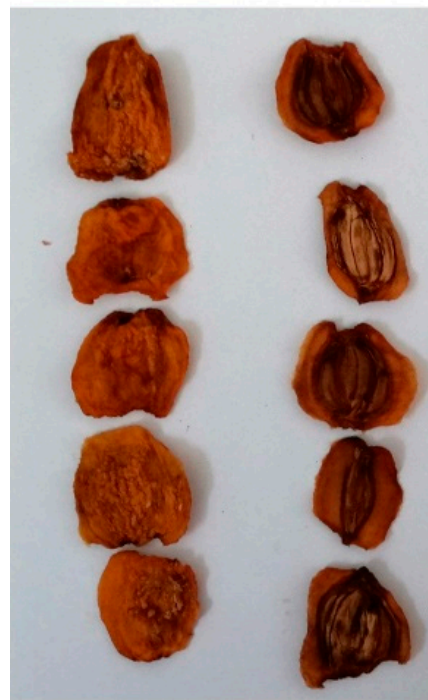

b

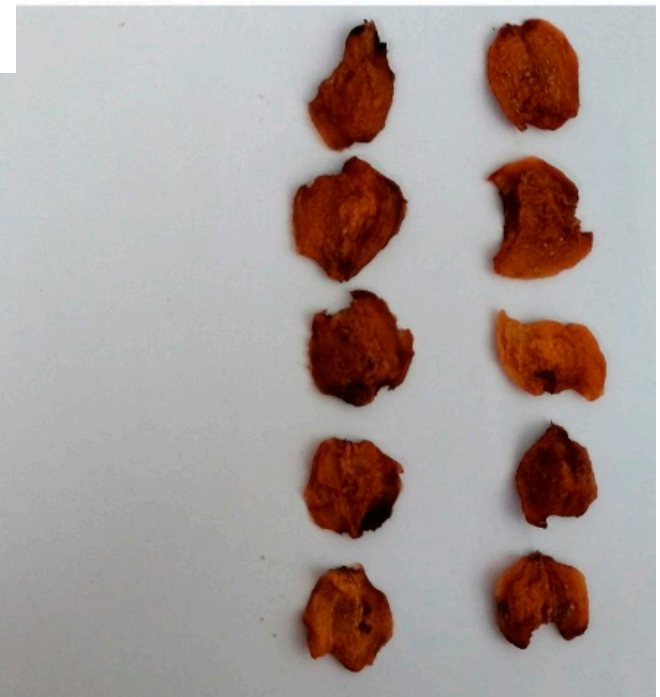

MAP P

MAP $\mathrm{N}_{2}$

Figure 1. A representative sample of the cultivars Claudia (a) and Peluche (b) after 50 days of storage with MAP $\mathrm{N}_{2}$ and MAP P treatment.

\subsection{Firmness}

The evolution of firmness of the dehydrated loquat slices over the period of storage is reported in Figure 2. Mechanical properties of the fruits are expected to change during storage [51] due to the alteration of their structural components that occurs during hot air drying [52]. Compared to the fresh fruit, white-fleshed dehydrated fruit appeared to lose more firmness at 0 days. Significant differences between passive and MAP $\mathrm{N}_{2}$ samples were only observed in the red-fleshed fruits until 20 days of storage, while no difference emerged between the treatments after this date. Overall, red-fleshed loquat slices retained a slightly 
higher firmness than the white-fleshed ones, but with no significant difference between the two groups. Throughout the storage period, we observed a slight decrease of firmness by fruits of all groups, which can be attributed to the loss of fruit turgor, compensated for by hardening due to the dehydration [53]. These results, however, are satisfactory if compared with studies conducted on several dehydrated fruits such as peach, pear, and apricot [54], which lose up to $99 \%$ of their firmness values. This is probably an effect of the controlled atmosphere storage of the fruit slices, as has been observed repeatedly by various authors [55-57].
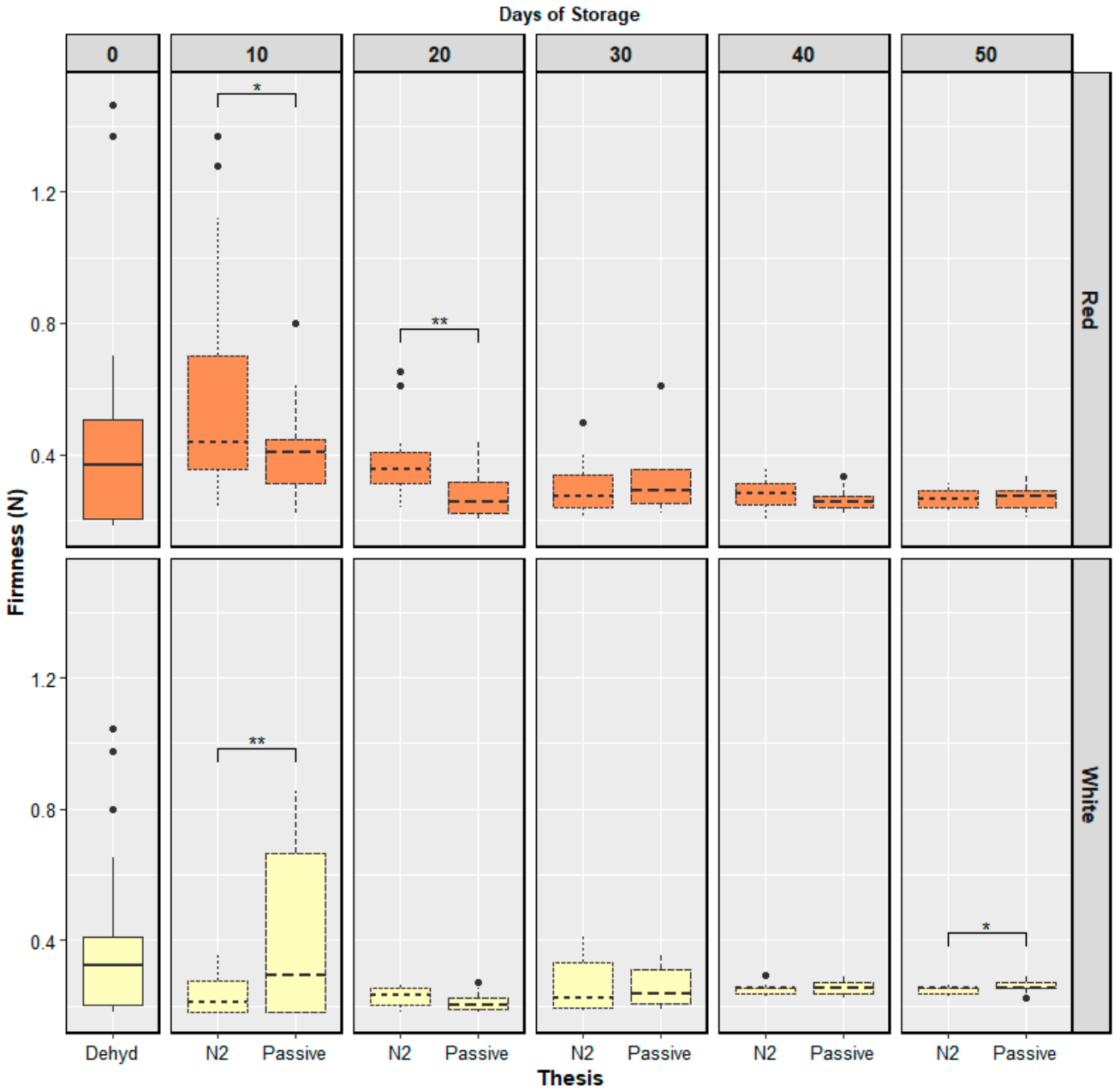

Figure 2. Firmness values of the dehydrated loquat slices over the period of storage. Asterisks between box plots indicate statistical significance of difference using Student's T-statistic with ${ }^{*}-p<0.05,{ }^{* *}-p<0.01$. No asterisk indicates a non-significant difference between the means of the treatments.

\subsection{Color Characteristics}

Median color of the dehydrated loquat slices is reported in Figures 3-5. The dehydration process obtained a product with higher chroma than the fresh fruit, with this value increasing from 26 and 42 for red- and white-fleshed fruit, respectively (Table 1), up to median values around 55 for both cultivars (Figure 3) In both white- and red-fleshed dehydrated loquat slices, we observed a decrease of both chroma and hue angle values after 20 days of storage (Figure 4), while significant differences between the treatments were only observed in red-fleshed loquat slices at 20 days of storage, where the MAP $\mathrm{N}_{2}$ treatment helped to retain a brighter color compared to the untreated control samples. In general, loquat flesh turns brown soon after the fruit are peeled. Browning is mostly caused by enzymatic processes involving especially polyphenolic compounds and PPO 
(polyphenol oxidase) [58-60]. Controlled or modified atmosphere packaging has been observed to maintain flesh color among other quality parameters [61]; this is confirmed by the results of our observations.

The color difference $\Delta E$ is presented in Figure 5. Up to 20 days of dehydration, both white- and red-fleshed loquat dehydrated slices maintained a low value of $\Delta E$, which reflects the fact that the color of the stored slices is similar to that of the just-dehydrated ones, while a major alteration in color of the slices was reached only after 30 days of storage. The only significant difference between the treatments was observed in red-fleshed loquat slices after 20 days of storage, where MAP P stored slices showed a higher color difference than the MAP N $\mathrm{N}_{2}$ stored ones. The results of our observations represent an improvement compared to the behavior of fresh-cut, non-dehydrated loquat fruit, which were observed to reach $\Delta E$ values of 20 after 10 days of cold storage [62]. Hence, we could conclude that the dehydration treatment allowed loquat slices, regardless of flesh color and packaging atmosphere, to maintain an attractive color until 20 days after dehydration, and significant nonenzymatic browning [63-65] started to manifest only after that moment.

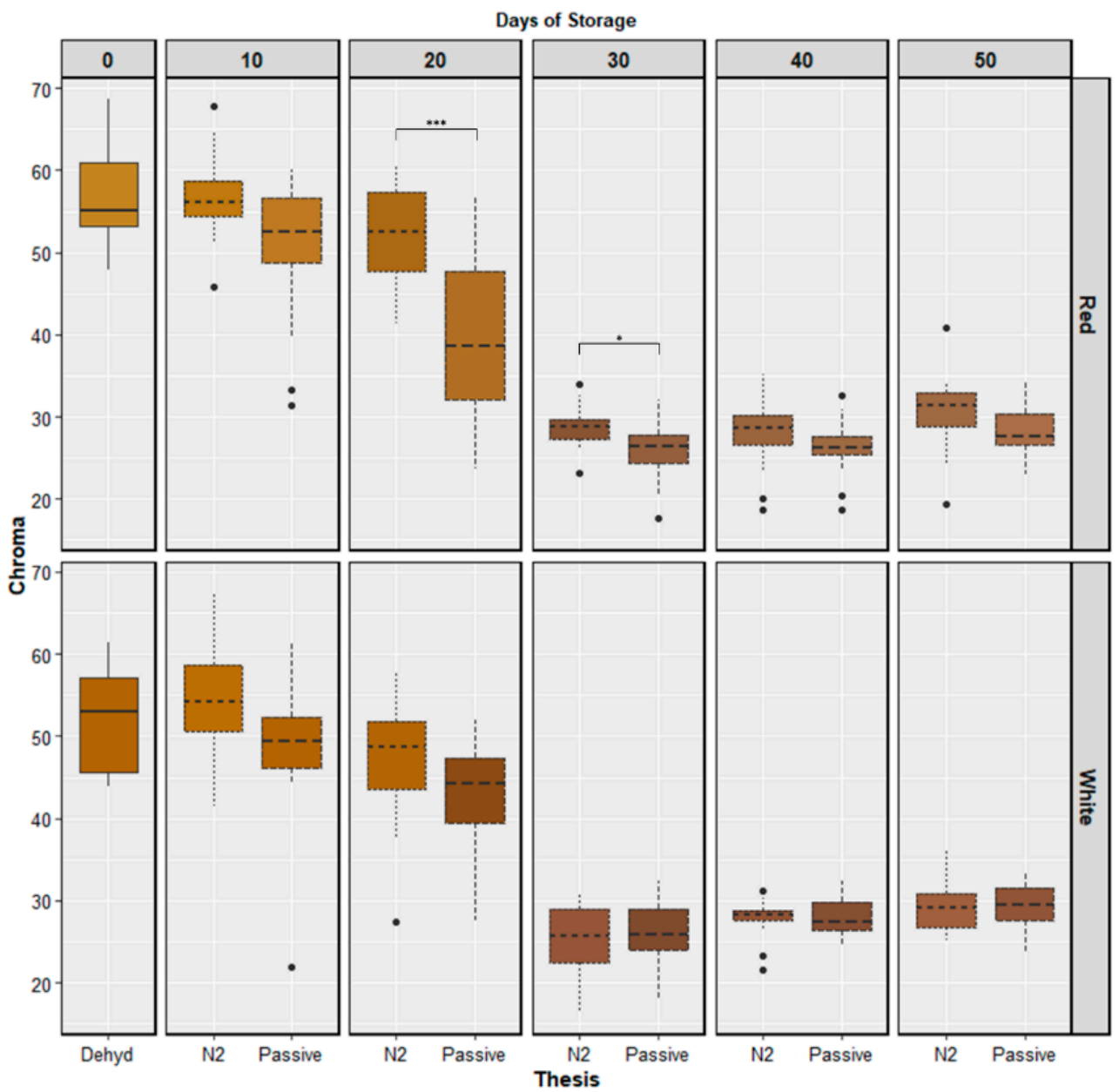

Figure 3. Chroma $\left(C^{*} a b\right)$ values of the dehydrated loquat samples analyzed over the course of the experiment. Box plots are filled with the median color value of the group, transformed from the CIE $L^{*} a^{*} b^{*}$ color space into printable hexadecimal values using the $\mathrm{R}$ package color-space. Asterisks between box plots indicate statistical significance of difference using Student's T-statistic, with ${ }^{*}-p<0.05$, and ${ }^{* * *}-p<0.001$. No asterisk indicates a non-significant difference between the means of the treatments.

\subsection{Microbial Analysis}

The microbiological characterization performed by plate count on the fresh and dehydrated slice loquat samples involved the microorganisms responsible for the microbial 
spoilage of fruits and vegetables [66], as well as the main human pathogens associated with agricultural products consumed raw [67]. The results of plate counts performed on fresh fruits of both cultivars object of study (Peluche and Claudia) showed detectable levels of the sole TMM and molds at about $10^{3} \mathrm{CFU} / \mathrm{g}$. Soon after dehydration at 50 or $70^{\circ} \mathrm{C}$ for $12 \mathrm{~h}$ and at each sampling time (T 10; T 20; T 30; T 40; T 50), all sliced loquat samples packaged with MAP P and MAP $\mathrm{N}_{2}$ were characterized by undetectable levels of all microbial groups investigated. The absence of microorganisms is imputable to the drying process, which reduces moisture percentage and free water necessary for the proliferation and survival of microorganisms [21], even though dry foods can be responsible for out-breaks caused by Cronobacter spp., E. coli, L. monocytogenes, Salmonella spp., and Staphylococcus spp. [68,69]. In particular, members of the genus Staphylococcus and Salmonella have been found in dried commercial samples of raisins and prunes [70], while E. coli, L. monocytogenes have shown the ability to survive on dried apricots [71]. To this purpose, the evaluation of microbial safety of dried fruits deserves particular attention.

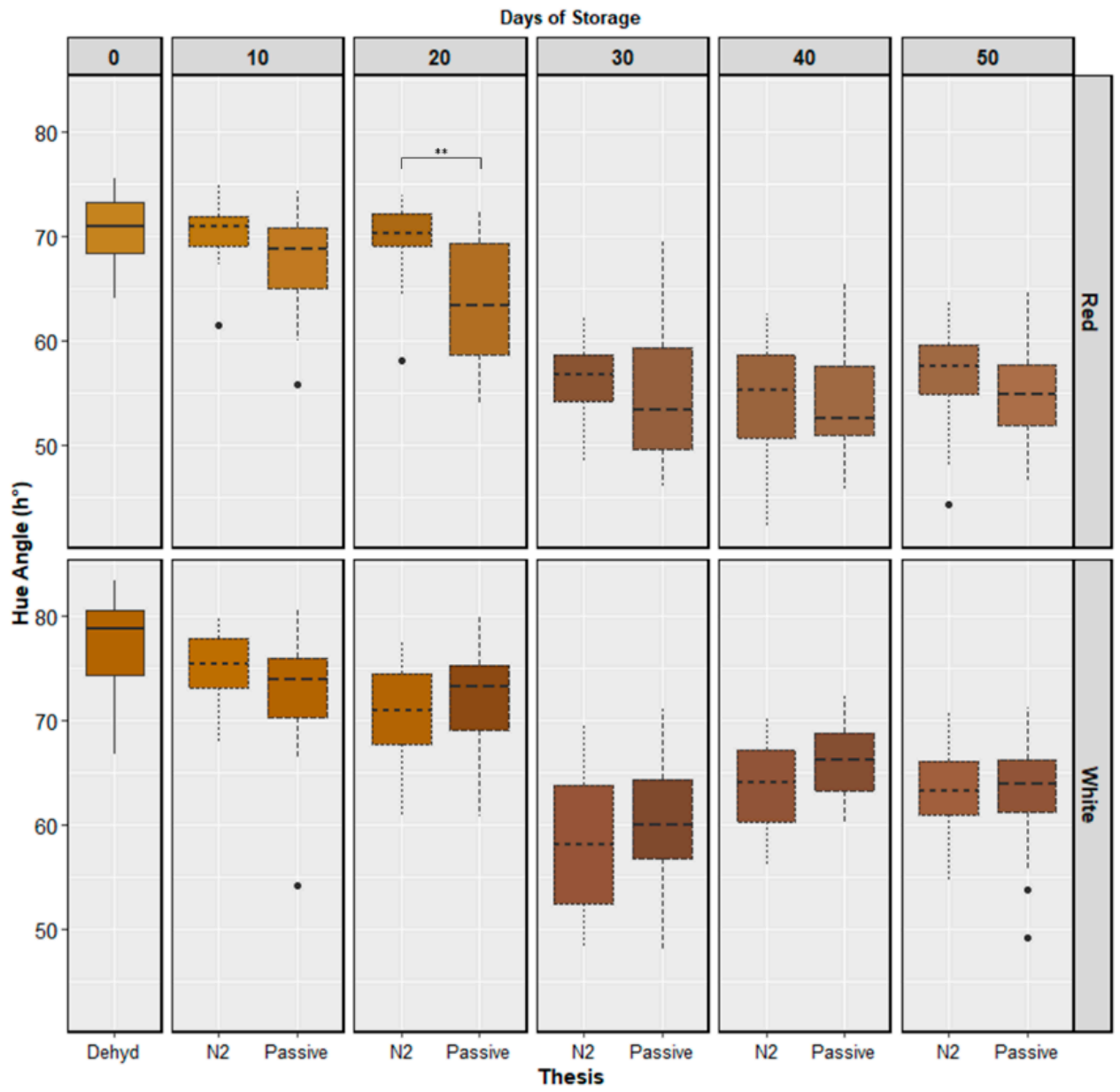

Figure 4. Hue angle $\left(h^{\circ}\right)$ values of the dehydrated loquat samples analyzed over the course of the experiment. Box plots are filled with the median color value of the group, transformed from the CIE $L^{*} a^{*} b^{*}$ color space into printable hexadecimal values using the $\mathrm{R}$ package color-space. Asterisks between box plots indicate statistical significance of difference using Student's T-statistic, with ** $-p<0.01$. No asterisk indicates a non-significant difference between the means of the treatments.

\subsection{Proximate Compounds}

The results show that the vitamin A and C content decreases immediately after the dehydration process of both white- and red-fleshed loquat fruits, probably due to prolonged exposure to high temperatures. Indeed, as vitamins are thermolabile, many studies confirm that their concentration is reduced during high temperature treatment [72]. In agreement 
with these studies, our work shows a greater reduction in vitamin A and C content just after the dehydration process, which lasted a total of $12 \mathrm{~h}$. Furthermore, to confirm this thesis, the data show that during the 50 days of storage, the fruits continue to lose their vitamin content, but not significantly, compared to the peak shown after the dehydration process. In particular, for the red-fleshed fruit (Peluche $\mathrm{Cv}$.), the initial vitamin A content was $0.89 \mathrm{mg} / 100 \mathrm{~g}$ of the flesh. After the dehydration process of $12 \mathrm{~h}$, there was a reduction in its content of $27.33 \%$; while, after 50 days of storage, the vitamin A content was reduced by a total of $36 \%$ (in MAP P) and $26 \%$ (in MAP $\mathrm{N}_{2}$ ). As for vitamin C (ascorbic acid), it had an initial value (fresh product) of $1.36 \mathrm{mg} / 100 \mathrm{~g}$ of flesh, which decreased by $49.67 \%$ immediately after dehydration. In the days following dehydration, storage with MA (modified atmospheres) resulted in a decrease of $48 \%$ of its concentration in MAP P and $38 \%$ in MAP $\mathrm{N}_{2}$, (after 50 days of storage). Furthermore, it was observed that by the tenth day of storage, the MAP P treatment had already lost 20 and 11\% of its vitamin A and $C$ content, respectively, while loquat slices stored in MAP $\mathrm{N}_{2}$ lost only $14 \%$ (vitamin A) and 5\% (vitamin C) of their content compared to the initial post-dehydration data. For the white-fleshed loquat fruit (Claudia Cv.), however, the initial value of the vitamin content was $0.70 \mathrm{mg}$ (vitamin A) and $1.17 \mathrm{mg}$ (vitamin C) per $100 \mathrm{~g}$ of the flesh. After the dehydration process, they lost about $35 \%$ and $5 \%$ of their initial content, respectively. After packaging and analysis for 50 days of storage, it was found that MAP P packaging resulted in a loss of vitamin $A$ and $C$ content of 45 and 55\% respectively, whereas MAP $\mathrm{N}_{2}$ packaging reduced the content of these vitamins by 30 and $38 \%$ compared to the initial value post dehydration. However, as found in other studies [73], loquat fruits have been shown to be a poor source of vitamin $\mathrm{C}$ considering, for example, that fruits such as oranges or apples contain about $40 \mathrm{mg}$ and $8 \mathrm{mg}$ of ascorbic acid, respectively, in $100 \mathrm{~g}$ of fresh produce, although this varies according to the cultivars analyzed [46]. Considering that consumers prefer commercial products not only because of their larger size, but also because they do not lose their organoleptic and nutraceutical characteristics [74], loquat fruits treated with the dehydration process and then packaged with MAP P and MAP $\mathrm{N}_{2}$ showed numerous differences. In fact, it is worth mentioning that packaging with $\mathrm{N}_{2}$ resulted in the retention of the analyzed vitamins until the end of the monitoring period (50 days). Regarding the analysis of minerals, the content of $\mathrm{K}, \mathrm{Na}, \mathrm{Ca}, \mathrm{Mg}$, and $\mathrm{P}$ in $100 \mathrm{~g}$ of flesh was analyzed both at the time of cutting (as a fresh product at d0), after dehydration (12 h), and during the following 50 days of storage with the different MA. From Table 4, it is possible to notice how the dehydration treatment determined a different performance according to the minerals analyzed. In particular, the $\mathrm{K}$ and $\mathrm{P}$ content decreased from $\mathrm{d} 0$ to $\mathrm{d} 50$, while the concentration of the other minerals $(\mathrm{Na}, \mathrm{Ca}$, and $\mathrm{Mg}$ ) increased. According to some studies [75] the lower the water content, the higher the concentration of minerals. In addition, some significant differences were found, as shown in the table, which indicate different behaviors of the packaging methods, particularly during the last days of storage. The statistics show that there is a clear maintenance of the mineral content in the treated loquat slices packed with MAP $\mathrm{N}_{2}$. There seems to be a difference of about $20 \%$ in the mineral content on the last day of storage between MAP P and MAP N 2 . On the differences between the two cultivars (Peluche and Claudia), it is not reasonable to compare these data because the initial concentrations at the time of cutting were different, so it was not possible to determine any differences in mineral content between the red-fleshed and the white-fleshed cultivars. Although the identification of this data is crucial, it was not possible to compare it with other literature data, as there are no studies carried out on the analysis of minerals and proximate compounds in general for dehydrated loquat fruits. In addition, $\mathrm{Ca}, \mathrm{K}$, and $\mathrm{P}$, together with a low $\mathrm{Na}$ intake, are associated with protection against bone demineralization, arterial hypertension, insulin resistance, and overall cardiovascular risk. Therefore, it was essential to highlight the content of these compounds in loquat fruits and to analyze any differences in order to identify the most appropriate preservation method for better retention of these compounds in the flesh. 


\subsection{Sensory Analysis}

A sensory analysis was conducted by a panel over the period of storage of the dehydrated loquat slices. Results of the panel evaluations are presented in Figure 6. The descriptors which, over the time of the experiment, always obtained the highest scores were odor of honey $(\mathrm{OH})$, flavor of caramel (FC), and sweet (SW). The negative descriptors off odor (OO), acid (A), and sour (S), on the other hand, were the ones which obtained the lowest scores throughout the storage period, No significant differences emerged between the MAP $\mathrm{N}_{2}$ samples and the MAP $\mathrm{P}$ at any given observation moment, but it is possible to notice a decrease in the scores obtained in some of the descriptors over time: in particular, the descriptors juiciness (JUI) and flavor of loquat (FL) are the ones that showed the biggest decrease in scores in the evaluation by the panel members.
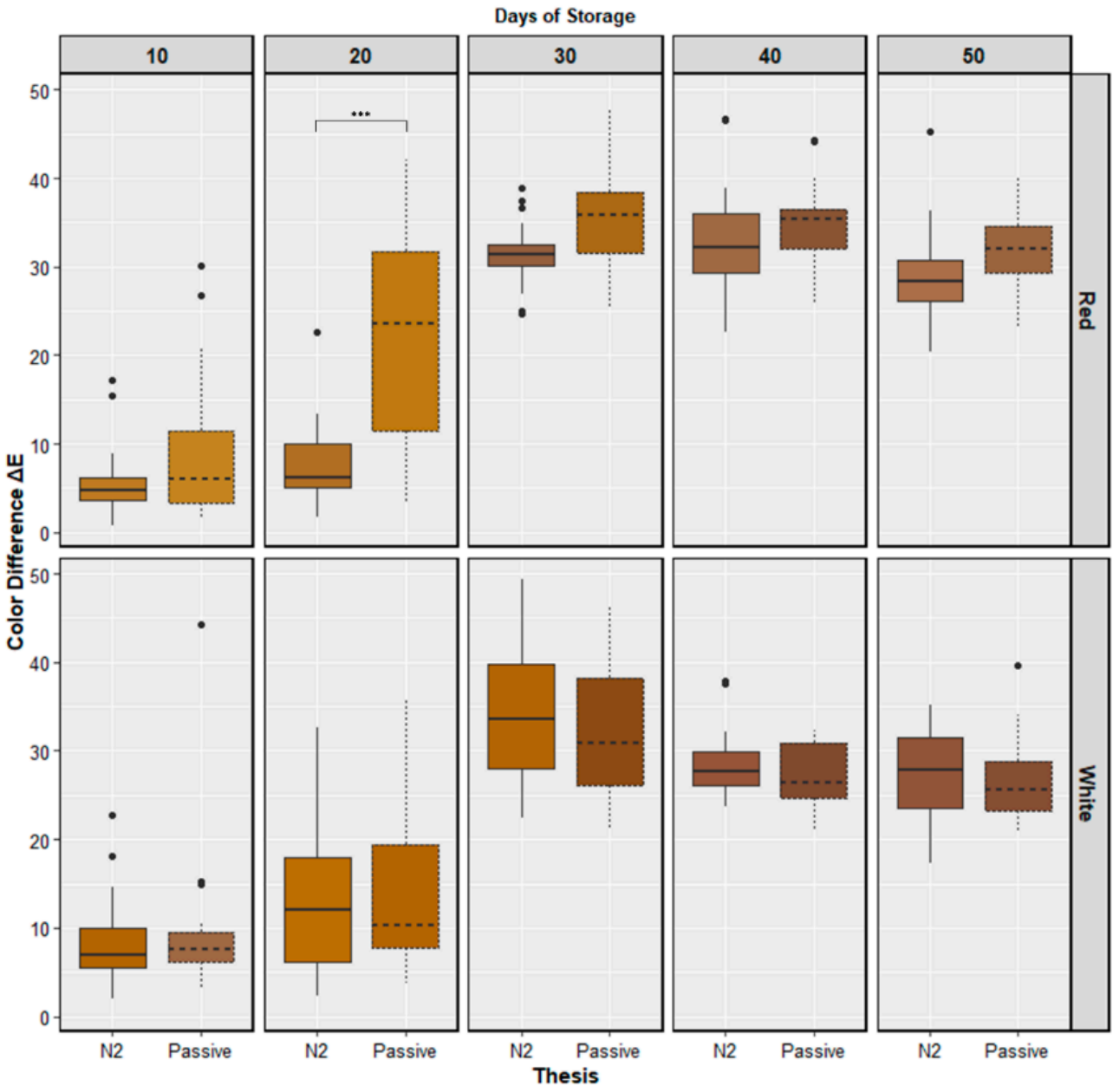

Figure 5. Color difference $(\Delta E)$ of the dehydrated loquat slices compared after the various storage times compared to the color measured on the freshly dehydrated slices just after the dehydration process. Box plots are filled with the median color value of the group, transformed from the CIE $L^{*} a^{*} b^{*}$ color space into printable hexadecimal values using the $\mathrm{R}$ package color-space. Asterisks between box plots indicate statistical significance of difference using Student's T-statistic, with $* * * p<0.001$. No asterisk indicates a non-significant difference between the means of the treatments. 
Table 4. Content of $\mathrm{K}, \mathrm{Na}, \mathrm{Ca}, \mathrm{Mg}$, and $\mathrm{P}$ per $100 \mathrm{~g}$ of fresh product, dehydrated $\left(\mathrm{T}_{0}\right)$ and after 10 , $20,30,40$, and 50 days of storage with MAP P and MAP $N_{2}$. The table shows means $\pm \operatorname{SD}(n=3)$; lower case letters show statistically significant differences $(p \leq 0.05)$ and the * indicates statistically significant differences between minerals in fruit packed with different MAP.

\begin{tabular}{|c|c|c|c|c|c|}
\hline \multicolumn{6}{|c|}{ Peluche Cv.-Mineral Composition (mg/100 g) } \\
\hline \multicolumn{6}{|c|}{ MAP P } \\
\hline & $\mathbf{K}$ & $\mathrm{Na}$ & $\mathrm{Ca}$ & $\mathrm{Mg}$ & $\mathbf{P}$ \\
\hline Fresh & $228.66 \pm 2.79 \mathrm{a}$ & $10.66 \pm 1.51 \mathrm{~b}$ & $15.00 \pm 1.00 \mathrm{c}$ & $11.66 \pm 1.08 \mathrm{~d}$ & $23.00 \pm 1.36 \mathrm{a}$ \\
\hline $\mathrm{T}_{0}$ & $205.00 \pm 2.50 \mathrm{~b}$ & $12.00 \pm 1.00 \mathrm{ab}$ & $15.66 \pm 1.15 c$ & $12.00 \pm 2.00 \mathrm{c}$ & $11.66 \pm 1.00 \mathrm{~b}$ \\
\hline $\mathrm{T}_{10}$ & $201.00 \pm 2.06 b^{*}$ & $13.66 \pm 2.00 \mathrm{a}$ & $20.67 \pm 1.00 \mathrm{bc}$ & $13.66 \pm 1.06 \mathrm{bc}$ & $11.66 \pm 1.06 \mathrm{~b}$ \\
\hline $\mathrm{T}_{20}$ & $196.66 \pm 2.00 \mathrm{~b}$ & $13.75 \pm 2.00 \mathrm{a}$ & $20.70 \pm 1.31 \mathrm{~b}$ & $14.66 \pm 1.06 \mathrm{~b}$ & $11.33 \pm 1.15 b$ \\
\hline $\mathrm{T}_{30}$ & $190.00 \pm 2.00 \mathrm{c}$ & $14.00 \pm 2.00 \mathrm{a}$ & $21.25 \pm 2.00 \mathrm{~b}$ & $14.66 \pm 1.00 \mathrm{~b}$ & $10.66 \pm 1.53 \mathrm{bc}$ \\
\hline $\mathrm{T}_{40}$ & $162.27 \pm 2.00 \mathrm{~d}^{*}$ & $14.00 \pm 2.31 \mathrm{a}$ & $21.50 \pm 1.00 \mathrm{ab}$ & $16.66 \pm 1.00 \mathrm{a}$ & $10.66 \pm 1.53 \mathrm{bc}$ \\
\hline $\mathrm{T}_{50}$ & $143.33 \pm 2.90 \mathrm{e}^{*}$ & $14.00 \pm 2.00 \mathrm{a}$ & $22.00 \pm 1.00 \mathrm{a}$ & $16.66 \pm 1.08 \mathrm{a}$ & $9.66 \pm 1.50 \mathrm{c}$ \\
\hline \multicolumn{6}{|c|}{ MAP N 2} \\
\hline & $\mathbf{K}$ & $\mathrm{Na}$ & $\mathrm{Ca}$ & $\mathrm{Mg}$ & $\mathbf{P}$ \\
\hline Fresh & $228.66 \pm 2.79 \mathrm{a}$ & $10.66 \pm 1.51 \mathrm{e}$ & $15.00 \pm 1.00 \mathrm{e}$ & $11.66 \pm 2.08 \mathrm{~d}$ & $23.00 \pm 4.36 \mathrm{a}$ \\
\hline $\mathrm{T}_{0}$ & $205.00 \pm 2.50 \mathrm{~b}$ & $12.00 \pm 1.00 \mathrm{~d}$ & $15.66 \pm 1.15 \mathrm{de}$ & $12.00 \pm 2.00 \mathrm{c}$ & $11.66 \pm 1.00 \mathrm{~b}$ \\
\hline $\mathrm{T}_{10}$ & $196.67 \pm 2.88 b c^{*}$ & $13.66 \pm 1.30 \mathrm{~cd}$ & $16.00 \pm 3.05 \mathrm{~d}$ & $13.66 \pm 1.57 \mathrm{~b}$ & $11.67 \pm 3.04 \mathrm{~b}$ \\
\hline $\mathrm{T}_{20}$ & $195.00 \pm 2.00 \mathrm{c}$ & $14.00 \pm 2.00 \mathrm{c}$ & $16.00 \pm 2.00 \mathrm{~d}$ & $13.66 \pm 1.52 \mathrm{~b}$ & $11.00 \pm 1.00 \mathrm{c}$ \\
\hline $\mathrm{T}_{30}$ & $191.33 \pm 2.30 \mathrm{~cd}$ & $14.00 \pm 2.00 \mathrm{c}$ & $18.00 \pm 2.08 c$ & $14.67 \pm 3.05 \mathrm{ab}$ & $10.66 \pm 1.52 c$ \\
\hline $\mathrm{T}_{40}$ & $190.00 \pm 2.00 \mathrm{~d}^{*}$ & $15.00 \pm 1.08 \mathrm{~b}$ & $20.00 \pm 1.00 \mathrm{~b}$ & $14.66 \pm 2.08 \mathrm{ab}$ & $10.66 \pm 1.27 c$ \\
\hline $\mathrm{T}_{50}$ & $173.33 \pm 2.00 \mathrm{e}^{*}$ & $17.00 \pm 2.01 \mathrm{a}$ & $22.00 \pm 3.60 \mathrm{a}$ & $15.00 \pm 1.52 \mathrm{a}$ & $9.00 \pm 1.53 \mathrm{~d}$ \\
\hline \multicolumn{6}{|c|}{ Claudia Cv.-Mineral Composition (mg/100 g) } \\
\hline \multicolumn{6}{|c|}{ MAP P } \\
\hline & K & $\mathrm{Na}$ & $\mathrm{Ca}$ & $\mathrm{Mg}$ & $\mathbf{P}$ \\
\hline Fresh & $128.66 \pm 2.79 \mathrm{a}$ & $24.00 \pm 2.64 \mathrm{e}$ & $15.00 \pm 1.00 \mathrm{~d}$ & $11.66 \pm 2.08 \mathrm{e}$ & $11.00 \pm 1.00 \mathrm{a}$ \\
\hline $\mathrm{T}_{0}$ & $110.00 \pm 2.00 \mathrm{~b}$ & $28.00 \pm 2.00 \mathrm{de}$ & $15.00 \pm 1.00 \mathrm{~d}$ & $11.00 \pm 1.03 \mathrm{e}$ & $11.66 \pm 1.51 \mathrm{ab}$ \\
\hline $\mathrm{T}_{10}$ & $105.00 \pm 2.00 \mathrm{c}$ & $29.00 \pm 2.00 \mathrm{~d}$ & $15.66 \pm 1.15 \mathrm{~d}^{*}$ & $13.66 \pm 0.57 \mathrm{~d}$ & $11.66 \pm 1.52 \mathrm{ab}$ \\
\hline $\mathrm{T}_{20}$ & $103.33 \pm 2.72 \mathrm{~d}$ & $31.00 \pm 1.60 c$ & $17.00 \pm 2.00 c^{*}$ & $14.00 \pm 0.11 \mathrm{~cd}$ & $11.66 \pm 1.52 \mathrm{ab}$ \\
\hline $\mathrm{T}_{30}$ & $101.33 \pm 2.00 \mathrm{e}$ & $33.66 \pm 2.30 \mathrm{bc}$ & $22.00 \pm 2.00 \mathrm{~b}$ & $14.66 \pm 1.05 c$ & $11.66 \pm 1.52 \mathrm{ab}$ \\
\hline $\mathrm{T}_{40}$ & $101.00 \pm 2.93 \mathrm{e}$ & $34.00 \pm 1.63 b^{*}$ & $25.00 \pm 1.00 \mathrm{a}$ & $21.00 \pm 1.08 b^{*}$ & $9.00 \pm 1.00 \mathrm{~b}$ \\
\hline $\mathrm{T}_{50}$ & $100.00 \pm 1.90 \mathrm{f}$ & $41.00 \pm 1.00 \mathrm{a}$ & $25.00 \pm 1.00 \mathrm{a}$ & $23.00 \pm 0.57 a^{*}$ & $9.66 \pm 1.53 b$ \\
\hline \multicolumn{6}{|c|}{ MAP N 2} \\
\hline & $\mathbf{K}$ & $\mathrm{Na}$ & $\mathrm{Ca}$ & $\mathrm{Mg}$ & $\mathbf{P}$ \\
\hline Fresh & $128.66 \pm 2.79 \mathrm{a}$ & $24.00 \pm 2.64 \mathrm{e}$ & $15.00 \pm 1.00 \mathrm{~d}$ & $11.66 \pm 1.08 \mathrm{de}$ & $11.00 \pm 1.00 \mathrm{a}$ \\
\hline $\mathrm{T}_{0}$ & $110.00 \pm 1.62 b$ & $28.00 \pm 2.00 \mathrm{~d}$ & $15.00 \pm 1.00 \mathrm{~d}$ & $11.00 \pm 1.03 \mathrm{e}$ & $11.66 \pm 1.51 \mathrm{ab}$ \\
\hline $\mathrm{T}_{10}$ & $106.00 \pm 2.00 \mathrm{c}$ & $29.00 \pm 2.00 \mathrm{~cd}$ & $22.00 \pm 2.00 c^{*}$ & $11.66 \pm 1.5 \mathrm{de}$ & $11.33 \pm 1.52 b$ \\
\hline $\mathrm{T}_{20}$ & $105.00 \pm 2.00 \mathrm{~cd}$ & $31.00 \pm 1.00 \mathrm{c}$ & $22.66 \pm 1.30 b^{*}$ * & $12.00 \pm 1.05 \mathrm{~d}$ & $10.66 \pm 1.15 c$ \\
\hline $\mathrm{T}_{30}$ & $103.33 \pm 2.72 \mathrm{~d}$ & $31.00 \pm 1.00 \mathrm{c}$ & $23.00 \pm 2.00 \mathrm{~b}$ & $13.66 \pm 0.50 c$ & $10.66 \pm 1.52 c$ \\
\hline $\mathrm{T}_{40}$ & $103.33 \pm 2.58 \mathrm{~d}$ & $41.00 \pm 1.00 b^{*}$ & $25.00 \pm 1.00 \mathrm{a}$ & $14.66 \pm 0.57 b$ * & $9.66 \pm 1.53 \mathrm{~d}$ \\
\hline $\mathrm{T}_{50}$ & $101.33 \pm 2.93 \mathrm{e}$ & $44.00 \pm 2.45 \mathrm{a}$ & $25.00 \pm 1.00 \mathrm{a}$ & $16.66 \pm 1.27 \mathrm{a}^{*}$ & $9.00 \pm 1.06 \mathrm{~d}$ \\
\hline
\end{tabular}




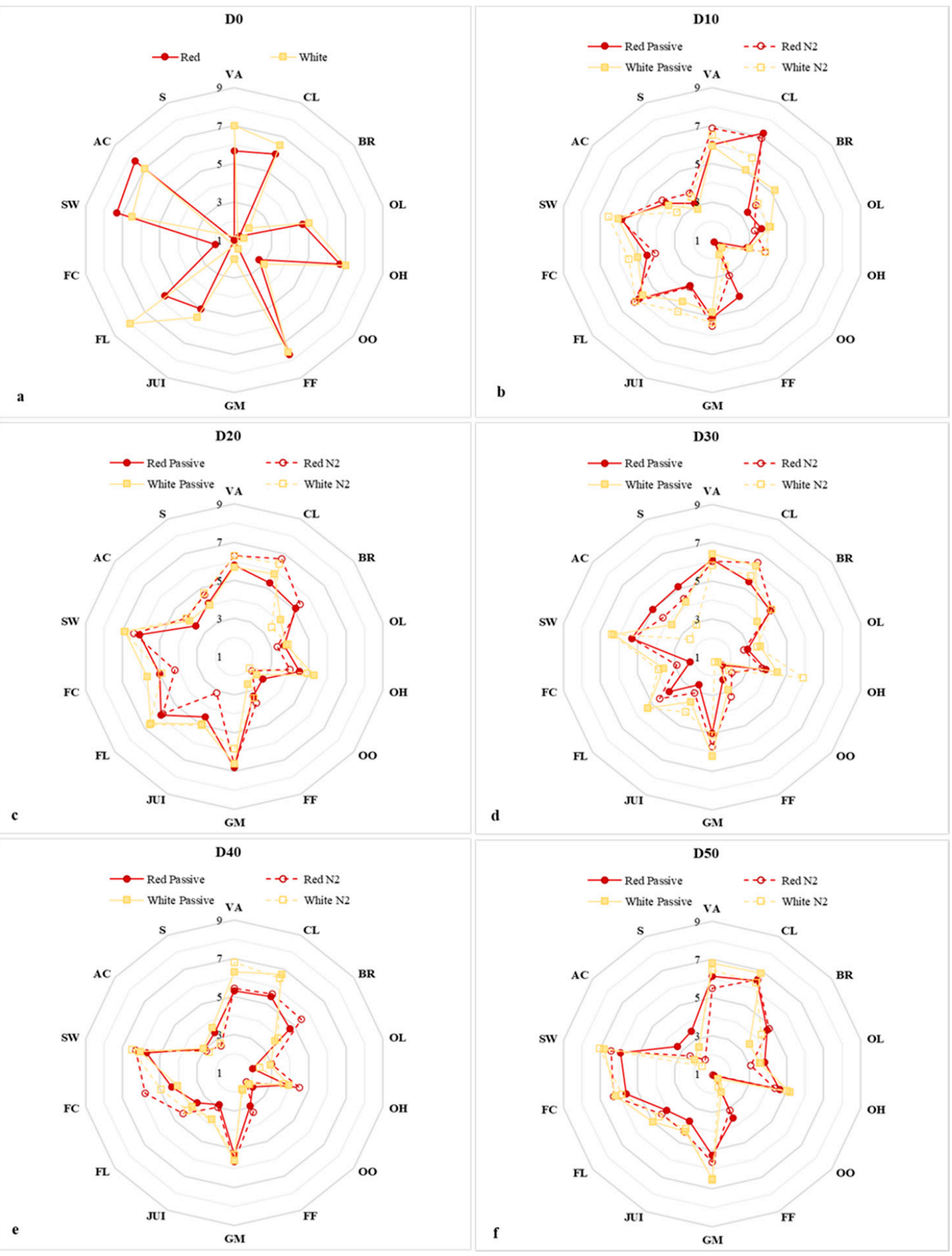

Figure 6. Results of the sensory analysis conducted on the dehydrated loquat slices at $0(\mathbf{a}), 10(\mathbf{b})$, 20 (c), 30 (d), 40 (e), and 50 (f) days of storage. Legend: visual appearance (VA); color (CL); browning (BR); loquat odor (OL); honey odor $(\mathrm{OH})$; off-odor (OO); crispness (FF); softness (GM); juiciness (JUI); loquat flavor (FL); caramel flavor (FC); sweetness (SW); acidity (AC); sourness (SO).

\section{Conclusions}

Our results highlights that the tray drying treatment at $70^{\circ}$ for $12 \mathrm{~h}$ had a good drying efficiency to obtain high quality loquat slices for both white- and red-fleshed loquat fruit. 
The dehydration process, as can be clearly seen in the reduction in the size of the slices (LD and TD), ensured that the water contained in the fresh fruit was properly removed, resulting in a product with a high shelf life, as evidenced by the number of days it was been stored. Firmness of the loquat slices changed slightly during storage due to the alteration of their structural components, which occurs during hot air drying. However, firmness was pleasant to the mouth, as confirmed by the sensory analysis results, which showed a positive rating for most descriptors, including the defect ratings. Slices maintained an attractive color after dehydration, and MAP treatments limited significant nonenzymatic browning for a long period of storage. From the microbiological point of view, both dehydration and MAP treatments maintained food safety, since all sliced loquat samples were characterized by undetectable levels of all microbial groups investigated after up to 50 days of storage.

From an applicative perspective, convective tray drying makes it possible to use loquat fruit that would have been excluded from the market and to position them usefully as processed products by enhancing the value of supply chain waste. The approach is useful on a small scale, but could be also easily industrialized.

Author Contributions: Conceptualization, V.F.; methodology, I.T., A.P. and E.P., formal analysis, I.T., A.P., D.S., E.P. and R.P.; investigation, R.P.; resources, V.F. and R.G.; data curation, D.S. and I.T.; writing — original draft preparation, I.T., R.P., D.S. and A.P.; writing—review and editing, V.F. and R.G.; supervision, V.F. and R.G. All authors have read and agreed to the published version of the manuscript.

Funding: This research received no external funding.

Informed Consent Statement: Not applicable.

Data Availability Statement: The data presented in this study are available on request from the corresponding author.

Acknowledgments: The authors would like to thank Vincenzo Guarino, who discussed this work as his MSc graduation thesis. A special acknowledgement should be addressed to "Lo Giudice" farm for the fruits used in this experiment and MedicAir Food S.r.l. and Orved S.p.a. for its collaboration in the research activity and making available the instrumentation needed to carry out the research.

Conflicts of Interest: The authors declare no conflict of interest.

\section{References}

1. Monastra, F.; Insero, O. The Present Situation of Some Underutilized Fruit Crops in Italy. Cah. Options Méditerranéennes 1995, 13, 39-46.

2. $\quad$ Llácer, G.; Badenes, M.; Calvo, J.M. Plant Material of Loquat in Mediterranean Countries; CIHEAM: Zaragoza, Spain, 2003; Volume 58 , pp. 45-52.

3. Testa, R.; Migliore, G.; Schifani, G.; Tinebra, I.; Farina, V. Chemical-Physical, Sensory Analyses and Consumers' Quality Perception of Local vs. Imported Loquat Fruits: A Sustainable Development Perspective. Agronomy 2020, 10, 870. [CrossRef]

4. Farina, V.; Gianguzzi, G.; Mazzaglia, A. Fruit Quality Evaluation of Affirmed and Local Loquat (Eriobotrya japonica Lindl) Cultivars Using Instrumental and Sensory Analyses. Fruits 2016, 71, 105-113. [CrossRef]

5. Planeta, D.; Farina, V.; Bambina, P.; Tinebra, I.; Passafiume, R.; Cinquanta, L.; Corona, O. Analysis of Aroma Compounds of Nine Autochthonous and Non-Autochthonous Loquat Cultivars Grown in Sicily. Ital. J. Food Sci. 2021, 33, 33-42. [CrossRef]

6. Gentile, C.; Reig, C.; Corona, O.; Todaro, A.; Mazzaglia, A.; Perrone, A.; Gianguzzi, G.; Agusti, M.; Farina, V. Pomological Traits, Sensory Profile and Nutraceutical Properties of Nine Cultivars of Loquat (Eriobotrya japonica Lindl.) Fruits Grown in Mediterranean Area. Plant Foods Hum. Nutr. 2016, 71, 330-338. [CrossRef]

7. Hou, Y.; Li, Z.; Zheng, Y.; Jin, P. Effects of $\mathrm{CaCl}_{2}$ Treatment Alleviates Chilling Injury of Loquat Fruit (Eribotrya japonica) by Modulating ROS Homeostasis. Foods 2021, 10, 1662. [CrossRef]

8. Fahim Abbas, M.; Batool, S.; Khaliq, S.; Mubeen, S.; Ullah, N.; Zafar, K.; Rafiq, M.; Al-Sadi, A.M.; Alotaibi, S.S.; El-Shehawi, A.M. Diversity of Fungal Pathogens Associated with Loquat and Development of Novel Virulence Scales. PLoS ONE 2021, 16, e0257951. [CrossRef]

9. Gonzalez-Dominguez, E.; Rossi, V.; Farina, V.; Gianguzzi, G.; Berbegal, M.; Armengol, J. Validation of a Mechanistic Model for Predicting Fruit Scab Infection on Different Loquat Cultivars. Phytopathol. Mediterr. 2017, 56, 400-408.

10. Gariglio, N.; Castillo, A.; Alós, E.; Juan, M.; Almela, V.; Agustı, M. The Influences of Environmental Factors on the Development of Purple Spot of Loquat Fruit (Eriobotrya japonica Lindl.). Sci. Hortic. 2003, 98, 17-23. [CrossRef] 
11. Avidan, B.; Klein, I. Physiological Disorders in Loquat (Eriobotrya japonica Lindl.). I. Russeting. Adv. Hortic. Sci. 1998, 12, 190-195.

12. Dhiman, A.; Suhag, R.; Thakur, D.; Gupta, V.; Prabhakar, P.K. Current Status of Loquat (Eriobotrya japonica Lindl.): Bioactive Functions, Preservation Approaches, and Processed Products. Food Rev. Int. 2021, 1-31. [CrossRef]

13. Pant, S.; Chinwan, D. Value Addition of Food Products. Int. J. Eng. Sci. Res. 2014, 4, 946-949.

14. Lewicki, P.P. Design of Hot Air Drying for Better Foods. Trends Food Sci. Technol. 2006, 17, 153-163. [CrossRef]

15. Mohite, A.; Mishra, A.; Sharma, N. Equilibrium Moisture Content and Drying Behaviour of Tamarind Seed under Thin Layer Condition. Int. J. Seed Spices 2016, 6, 18-22.

16. Macedo, L.L.; Vimercati, W.C.; da Silva Araújo, C.; Saraiva, S.H.; Teixeira, L.J.Q. Effect of Drying Air Temperature on Drying Kinetics and Physicochemical Characteristics of Dried Banana. J. Food Process Eng. 2020, 43, e13451. [CrossRef]

17. Caparino, O.; Tang, J.; Nindo, C.; Sablani, S.; Powers, J.; Fellman, J. Effect of Drying Methods on the Physical Properties and Microstructures of Mango (Philippine 'Carabao' Var.) Powder. J. Food Eng. 2012, 111, 135-148. [CrossRef]

18. Reis, R.C.; de Souza Viana, E.; Da Silva, S.C.S.; de Oliveira Mamede, M.E.; da Silva Araújo, Í.M. Stability and Sensory Quality of Dried Papaya. Food Nutr. Sci. 2018, 9, 489. [CrossRef]

19. Vidinamo, F.; Fawzia, S.; Karim, M. Investigation of the Effect of Drying Conditions on Phytochemical Content and Antioxidant Activity in Pineapple (Ananas comosus). Food Bioprocess Technol. 2021, 15, 72-81. [CrossRef]

20. Ullah, F.; Min, K.; Khattak, M.K.; Wahab, S.; Wahab, N.; Ameen, M.; Memon, M.S.; Wang, X.; Soomro, S.A.; Yousaf, K. Effects of Different Drying Methods on Some Physical and Chemical Properties of Loquat (Eriobotrya japonica) Fruits. Int. J. Fruit Sci. 2018, 18, 345-354. [CrossRef]

21. Mishra, A.; Upadhyay, A.; Jaiswal, P.; Sharma, N. Effect of Different Drying Method on the Chemical and Microstructural Properties of Loquat Slices. J. Food Process. Preserv. 2021, 45, e15105. [CrossRef]

22. Farina, V.; Cinquanta, L.; Vella, F.; Niro, S.; Panfili, G.; Metallo, A.; Cuccurullo, G.; Corona, O. Evolution of Carotenoids, Sensory Profiles and Volatile Compounds in Microwave-Dried Fruits of Three Different Loquat Cultivars (Eriobotrya japonica Lindl.). Plant Foods Hum. Nutr. 2020, 75, 200-207. [CrossRef]

23. Lahbari, M.; Fahloul, D. Experimental Study and Mathematical Modelling of Loquat Drying: Effect of the Drying Method on Quality. Int. Rev. Mech. Eng. IREME 2020, 14, 208. [CrossRef]

24. Mishra, A.; Sharma, N. Mathematical Modelling and Tray Drying Kinetics of Loquat (Eriobotrya japonica). J. Dairy Food Sci. 2014, 9 , 272-284. [CrossRef]

25. Dias, C.; Fonseca, A.; Amaro, A.L.; Vilas-Boas, A.A.; Oliveira, A.; Santos, S.A.; Silvestre, A.J.; Rocha, S.M.; Isidoro, N.; Pintado, M Natural-Based Antioxidant Extracts as Potential Mitigators of Fruit Browning. Antioxidants 2020, 9, 715. [CrossRef] [PubMed]

26. Suttirak, W.; Manurakchinakorn, S. Potential Application of Ascorbic Acid, Citric Acid and Oxalic Acid for Browning Inhibition in Fresh-Cut Fruits and Vegetables. Walailak J. Sci. Technol. WJST 2010, 7, 5-14.

27. Sadler, M.J.; Gibson, S.; Whelan, K.; Ha, M.-A.; Lovegrove, J.; Higgs, J. Dried Fruit and Public Health-What Does the Evidence Tell Us? Int. J. Food Sci. Nutr. 2019, 70, 675-687. [CrossRef] [PubMed]

28. Mossine, V.V.; Mawhinney, T.P.; Giovannucci, E.L. Dried Fruit Intake and Cancer: A Systematic Review of Observational Studies. Adv. Nutr. 2020, 11, 237-250. [CrossRef]

29. Martínez-Calvo, J.; Badenes, M.L.; Llácer, G.; Bleiholder, H.; Hack, H.; Meier, U. Phenological Growth Stages of Loquat Tree (Eriobotrya japonica (Thunb.) Lindl.). Ann. Appl. Biol. 1999, 134, 353-357. [CrossRef]

30. Caballero, P.; Fernández, M.A. Loquat, Production and Market. Options Mediterraéens Ser. Semin. Mediterr. 2003, 58 , 11-20.

31. Cisneros-Zevallos, L.; Krochta, J.M. Dependence of Coating Thickness on Viscosity of Coating Solution Applied to Fruits and Vegetables by Dipping Method. J. Food Sci. 2003, 68, 503-510. [CrossRef]

32. Fu, X.; Xing, S.; Xiong, H.; Min, H.; Zhu, X.; He, J.; Feng, J.; Mu, H. Effects of Packaging Materials on Storage Quality of Peanut Kernels. PLoS ONE 2018, 13, e0190377. [CrossRef] [PubMed]

33. Polenta, G.; Budde, C.; Murray, R. Effects of Different Pre-Storage Anoxic Treatments on Ethanol and Acetaldehyde Content in Peaches. Postharvest Biol. Technol. 2005, 38, 247-253. [CrossRef]

34. Metodo Per la Deterimanzione del Residuo Secco o Sostanza Secca-Gazzetta Ufficiale.Pdf. Available online: https: / / www.gazzettaufficiale.it/do/atto/serie_generale/caricaPdf?cdimg=12A0671700200010110001\&dgu=2012--06-14\&art. dataPubblicazioneGazzetta=2012--06-14\&art.codiceRedazionale=12A06717\&art.num=1\&art.tiposerie=SG (accessed on 1 January 2022).

35. Passafiume, R.; Gugliuzza, G.; Gaglio, R.; Busetta, G.; Tinebra, I.; Sortino, G.; Farina, V. Aloe-Based Edible Coating to Maintain Quality of Fresh-Cut Italian Pears (Pyrus communis L.) during Cold Storage. Horticulturae 2021, 7, 581. [CrossRef]

36. Passafiume, R.; Gaglio, R.; Sortino, G.; Farina, V. Effect of Three Different Aloe Vera Gel-Based Edible Coatings on the Quality of Fresh-Cut "Hayward" Kiwifruits. Foods 2020, 9, 939. [CrossRef]

37. Barros, L.; Baptista, P.; Ferreira, I.C. Effect of Lactarius Piperatus Fruiting Body Maturity Stage on Antioxidant Activity Measured by Several Biochemical Assays. Food Chem. Toxicol. 2007, 45, 1731-1737. [CrossRef]

38. Morand, C.-A. Les Recommendations, Les Resolutions et Les Avis Du Droit Communautaire. Cah. Dr Euro 1970, 6, 623.

39. Tinebra, I.; Scuderi, D.; Sortino, G.; Inglese, P.; Farina, V. Effects of Argon-Based and Nitrogen-Based Modified Atmosphere Packaging Technology on the Quality of Pomegranate (Punica granatum L. Cv. Wonderful) Arils. Foods 2021, 10, 370. [CrossRef]

40. Mazzaglia, A.; Lanza, C.; Farina, V.; Barone, F. Evaluation of Fruit Quality in Loquat Using Both Chemical and Sensory Analyses. In Proceedings of the III International Symposium on Loquat 887, Antakya-Hatay, Turkey, 3-6 May 2010; pp. 345-349. 
41. Stellfeldt, A.; Martín, J.J.H. Dinámica de Crecimiento del Fruto en Níspero Japonés 'Algerie' bajo Tratamiento de Riego Deficitario Precosecha. Available online: http: / / www.sech.info/ACTAS / Acta $\% 20$ n $\%$ C2 $\% B A \% 2054 . \% 20 V I \% 20$ Congreso $\% 20 \mathrm{Ib} \%$ C3\%A9 rico $\% 20 \mathrm{de} \% 20$ Ciencias $\% 20$ Hort $\%$ C3\%ADcolas.\%20XII\%20Congreso $\% 20$ Nacional $\% 20 \mathrm{de} \% 20$ Ciencias $\% 20 \mathrm{Hort} \% \mathrm{C} 3 \%$ ADcolas / Comunicaciones/Din \%C3\%A1mica \%20de \%20crecimiento $\% 20 \mathrm{del} \% 20$ fruto $\% 20 \mathrm{en} \% 20 \mathrm{n} \% \mathrm{C3} \%$ ADspero $\% 20 \mathrm{japon} \% \mathrm{C} \%$ A9s $\%$ 20\%E2\%80\%98Algerie $\%$ E2\%80\%99\%20bajo\%20tratamiento $\% 20$ de $\% 20$ riego $\% 20$ deficitario $\% 20$ precosecha.pdf (accessed on 1 January 2022).

42. Zhou, C.-H.; Xu, C.-J.; Sun, C.-D.; Li, X.; Chen, K.-S. Carotenoids in White-and Red-Fleshed Loquat Fruits. J Agric. Food Chem. 2007, 55, 7822-7830. [CrossRef]

43. McGuire, R.G. Reporting of Objective Color Measurements. HortScience 1992, 27, 1254-1255. [CrossRef]

44. Insero, O.; Monastra, F.; Barone, F.; Calabrese, F.; D’Ascanio, R.; Martelli, S.; Ondradu, G. Loquat Tree (Eriobotrya japonica Lindl.). Inf. Agrar. 1993, 12, 64-66. (In Italian)

45. Xu, H.; Chen, J. Commercial Quality, Major Bioactive Compound Content and Antioxidant Capacity of 12 Cultivars of Loquat (Eriobotrya japonica Lindl.) Fruits. J. Sci. Food Agric. 2011, 91, 1057-1063. [CrossRef] [PubMed]

46. Hasegawa, P.N.; Faria, A.F.d.; Mercadante, A.Z.; Chagas, E.A.; Pio, R.; Lajolo, F.M.; Cordenunsi, B.R.; Purgatto, E. Chemical Composition of Five Loquat Cultivars Planted in Brazil. Ciênc. E Tecnol. Aliment. 2010, 30, 552-559. [CrossRef]

47. Jayaraman, K.; Das Gupta, D. Dehydration of Fruits and Vegetables-Recent Developments in Principles and Techniques. Dry. Technol. 1992, 10,1-50. [CrossRef]

48. Tarancón, P.; Fernández-Serrano, P.; Besada, C. Consumer Perception of Situational Appropriateness for Fresh, Dehydrated and Fresh-Cut Fruits. Food Res. Int. 2021, 140, 110000. [CrossRef] [PubMed]

49. Rocculi, P.; Romani, S.; Dalla Rosa, M. Effect of MAP with Argon and Nitrous Oxide on Quality Maintenance of Minimally Processed Kiwifruit. Postharvest Biol. Technol. 2005, 35, 319-328. [CrossRef]

50. Soltani, M.; Alimardani, R.; Mobli, H.; Mohtasebi, S.S. Modified Atmosphere Packaging: A Progressive Technology for Shelf-Life Extension of Fruits and Vegetables. J. Appl. Packag. Res. 2015, 7, 2.

51. Alzamora, S.M.; Lopez Malo, A.; Tapia, M.S. Minimally Processed Fruits and Vegetables, 1st ed.; CRC Press: Boca Raton, FL, USA, 2000

52. Sagar, V.R.; Suresh Kumar, P. Recent Advances in Drying and Dehydration of Fruits and Vegetables: A Review. J. Food Sci. Technol. 2010, 47, 15-26. [CrossRef]

53. Moreno, J.; Chiralt, A.; Escriche, I.; Serra, J.A. Effect of Blanching/Osmotic Dehydration Combined Methods on Quality and Stability of Minimally Processed Strawberries. Food Res. Int. 2000, 33, 609-616. [CrossRef]

54. Bolin, H.R.; Huxsoll, C.C. Storage stability of minimally processed fruit. J. Food Process. Preserv. 1989, 13, 281-292. [CrossRef]

55. Rodrigues, A.C.C.; Pereira, L.M.; Sarantópoulos, C.I.G.L.; Bolini, H.M.A.; Cunha, R.L.; Junqueira, V.C.A.; Hubinger, M.D. Impact of Modified Atmosphere Packaging on the Osmodehydrated Papaya Stability. J. Food Process. Preserv. 2006, 30, 563-581. [CrossRef]

56. Moggia, C.; Lobos, G.A.; Retamales, J.B. Modified Atmosphere Packaging in Blueberries: Effect of Harvest Time and Moment of Bag Sealing. Acta Hortic. 2014, 153-158. [CrossRef]

57. Nielsen, T.; Leufvén, A. The Effect of Modified Atmosphere Packaging on the Quality of Honeoye and Korona Strawberries. Food Chem. 2008, 107, 1053-1063. [CrossRef]

58. Pareek, S.; Benkeblia, N.; Janick, J.; Cao, S.; Yahia, E.M. Postharvest Physiology and Technology of Loquat (Eriobotrya japonica Lindl.) Fruit. J. Sci. Food Agric. 2014, 94, 1495-1504. [CrossRef] [PubMed]

59. Zhang, X.; Shao, X. Characterisation of Polyphenol Oxidase and Peroxidase and the Role in Browning of Loquat Fruit. Czech J. Food Sci. 2016, 33, 109-117. [CrossRef]

60. Tian, S.; Li, B.; Ding, Z. Physiological Properties and Storage Technologies of Loquat Fruit. Fresh Prod. 2007, 1, 76-81.

61. Ding, C.-K.; Chachin, K.; Ueda, Y.; Imahori, Y.; Wang, C.Y. Modified Atmosphere Packaging Maintains Postharvest Quality of Loquat Fruit. Postharvest Biol. Technol. 2002, 24, 341-348. [CrossRef]

62. Sortino, G.; Allegra, A.; Farina, V.; De Chiara, M.L.V.; Inglese, P. Genotype Influence on Shelf Life Behaviour of Minimal Processed Loquat (Eriobotrya japonica (Thunb.) Lindl.) Fruit: The Role of Sugar, Acid Organics and Phenolic Compounds. Chem. Biol. Technol. Agric. 2022, 9, 8. [CrossRef]

63. Koca, N.; Burdurlu, H.S.; Karadeniz, F. Kinetics of Colour Changes in Dehydrated Carrots. J. Food Eng. 2007, 78, 449-455. [CrossRef]

64. Baloch, A.; Buckle, K.; Edwards, R. Measurement of Non-enzymic Browning of Dehydrated Carrot. J. Sci. Food Agric. 1973, 24, 389-398. [CrossRef]

65. Abano, E.E. Kinetics and Quality of Microwave-Assisted Drying of Mango (Mangifera Indica). Int. J. Food Sci. 2016, $2016,2037029$. [CrossRef]

66. Barth, M.; Hankinson, T.R.; Zhuang, H.; Breidt, F. Microbiological Spoilage of Fruits and Vegetables. In Compendium of the Microbiological Spoilage of Foods and Beverages; Springer: Berlin/Heidelberg, Germany, 2009; pp. 135-183.

67. Leff, J.W.; Fierer, N. Bacterial Communities Associated with the Surfaces of Fresh Fruits and Vegetables. PLoS ONE 2013, 8, e59310. [CrossRef] [PubMed]

68. Paswan, R.; Park, Y.W. Survivability of Salmonella and Escherichia Coli O157: H7 Pathogens and Food Safety Concerns on Commercial Powder Milk Products. Dairy 2020, 1, 189-201. [CrossRef]

69. Bintsis, T. Foodborne Pathogens. AIMS Microbiol. 2017, 3, 529. [CrossRef] [PubMed] 
70. Witthuhn, R.; Engelbrecht, S.; Joubert, E.; Britz, T. Microbial Content of Commercial South African High-moisture Dried Fruits. J. Appl. Microbiol. 2005, 98, 722-726. [CrossRef]

71. Liu, Z.; Liao, C.; Golson, K.; Phillips, S.; Wang, L. Survival of Common Foodborne Pathogens on Dried Apricots Made with and without Sulfur Dioxide Treatment. Food Control 2021, 121, 107569. [CrossRef]

72. Radojčin, M.; Pavkov, I.; Bursać Kovačević, D.; Putnik, P.; Wiktor, A.; Stamenković, Z.; Kešelj, K.; Gere, A. Effect of Selected Drying Methods and Emerging Drying Intensification Technologies on the Quality of Dried Fruit: A Review. Processes 2021, 9, 132. [CrossRef]

73. Seymour, G.B.; Taylor, J.E.; Tucker, G.A. Biochemistry of Fruit Ripening; Springer Science \& Business Media: Berlin/Heidelberg, Germany, 2012; ISBN 94-011-1584-2.

74. Sun, Y.; Liang, C. Factors Determining Consumers' Purchase Intentions Towards Dried Fruits. Int. J. Fruit Sci. 2020, 20, S1072-S1096. [CrossRef]

75. Farina, V.; Passafiume, R.; Tinebra, I.; Palazzolo, E.; Sortino, G. Use of Aloe Vera Gel-Based Edible Coating with Natural Anti-Browning and Anti-Oxidant Additives to Improve Post-Harvest Quality of Fresh-Cut 'Fuji'Apple. Agronomy 2020, 10, 515. [CrossRef] 